\title{
IS REVA A BETTER PREDICTOR OF SHAREHOLDERS' VALUE? A STUDY OF PAKISTANI LISTED CEMENT COMPANIES
}

\author{
YASIR ASHRAF \\ Institute of Business Administration, University of the Punjab
}

Quaid-e-Azam Campus,Lahore, Pakistan

\begin{abstract}
The effectiveness of traditional methods of measuring organizational financial performance is least in practice. Theorists have put forward contemporary financial performance measures but their significance is still under discussion by the researchers. In this study, the relative significance of modern measures of financial performance like REVA and EVA and traditional accounting-based measures is undergone for the cement sector of Pakistan using data from 2006 to 2014. After using descriptive statistics, correlation analysis, and regression estimation technique, the resultsindicate the irrelevance of $\mathrm{ROE}, \mathrm{ROA}$, and EPS as measures of financial performance while EVA as a modern measure was found to have a significant link with the long-term organizational performance. Lastly, REVA was also found asinsignificant and therefore irrelevant performance measure.However, the relative explanatory power of EVA is also weak implying that future investigations in this domain of knowledge should be considered with a view to explain long-term value of the organizations.

KEYWORDS: Refined Economic Value Added (REVA), Economic Value Added (EVA), Market-Adjusted Returns $(M A R)$
\end{abstract}

Received: Jan23, 2018; Accepted: Feb13, 2018; Published: Mar 02, 2018; Paper Id.: IJECRAPR20181

\section{INTRODUCTION}

Gone are the days whenprofit maximization was considered as the ultimate corporate objective. In today's competitive era, shareholders' wealth maximization and value maximization is recognized as the reason of survival for corporations. So, the focus of the organizations has been shifted towards this aspect of performance as it considers the long run cash generation prospects of the organization (Sharma \& Kumar, 2010). Therefore, a paradigm shift has occurred in the conception of performance evaluation of the organization. This also implies that traditional measures relying on past profits are no longer that effective.

A contemporary performance measure was devised with the name of Economic Value Added (EVA), which, later on, was adjusted to Refined Economic Value Added (REVA). This modified version of EVA measures the real amount of profit made by a firm after recovering the cost of capital based on market value of the relative source of financing(Bacidore, 1997). In conventional accounting, the concept of "economic profit" is overlooked by accountants but REVA overcomes this drawbackby providing "real profit" of the organization that represents the true potential of the firm.

The ultimate objective of decision-making activity is to generate cash flows in excess of the cost of capital. Any positive increment in the owners' wealth is considered a yardstick to measure the financial 
performance of the firm. This value-creation process looks easy but requires a tremendous effort of top management and employees of the organization. Value-creation is a long- term phenomenon of performance measurement. Through this, it is determined whether any economic value has been created by the management for the owners or not.

Conventional accounting measures like Return on Equity (ROE), Return on Assets (ROA), Return on Investment (ROI), Earnings per share (EPS), and Net income (NI) have been extensively used in the past for business performance measurement.Investors and management of the corporations used to consider these financial measures as appropriate measures of firm's performance. In particular, ROI was widely considered as the most powerful and ultimate performance measure of organizations(Reece, 1978). The findings of Jacobson(1987) also indicatedthe significant association between ROI and stock returns. The reason is that ROI gives the relationship between profits generated on the investment made in assets. But, recently, many studies indicate that ROI fails to account for the organizational value in the contemporary context (Chetty, Friedman, \&Rockoff, 2016). Despite widespread use,Harcourt (1965) andFisher (1983) have criticizedconventional accounting measures of performance as inadequate due to reliance on the past data and their tendency to get manipulated easily. According to them, ROI does not properly relate profits to the investment. Profits are the results of past investment decisions but assets have influence not only on past, present but also on future earnings. Further, accounting measures do not consider the cost of all capital invested to determine the true amount of profit (Stewart, 1991; Wang, 2013).

In order to address these deficiencies of the traditioanl performance measures, Stewart (1991) introduced Economic value added (EVA) as a new financial performance measure. He argued that EVA is a way to represent a firm's true performance as it reflects only economic profit added to a firm after recovering the cost of all capital invested. The studies conducted by Byrne (1996), Garvey (2000), Machuga (2002), Abdeen (2002), Desai (2006),Hassan (2014) and Baxendale and Bowen (2015)provided sufficient evidence to show that EVA is a better estimator of shareholders' wealth as compared to the traditional accounting performance measures i.e. ROI, ROA, ROE, EPS. The explanation is the importance given by investors to cost of capital for determining real profit made by the firms. These results verified the claim of Stewart (1991) on the relevance of EVA.Certain other studies provided contrary evidence. Ismail (2014) and Alipour \& Pejman (2015) investigated the explanatory power of contemporary measures but found these measures as irrelevant to performance measurement.

Bacidore et al. (1997) argued in the favor of REVA as compared to EVA and suggested that although EVA has been found to have explanatory power for the stock returns, REVA is theoretically superior measure of organizational performance as REVA provides an assessment on the operating performance of the firm in context of as to whether the performance is adequate for the payment of returns to the financers of the firm. The study comparatively assessed the impact of REVA and EVA on market value creation of the firm and confirmed that REVA is a better predictor of market value of the firm. The study confirmed the notions of superiority of REVA as compared to EVA, but evidence on the impact of traditional performance measures like ROA, ROE and EPS was also found. Lee (2009) and Pourali (2013) also investigated the relevance of REVA with value-creation by the firms and the findings observed significance of REVA in this regard.

Conversely,a number of studies in Iran like Panahian (2011), Moghaddam (2012), Arabsalehi (2012), and Chetty, Friedman andRockoff (2016),however, indicated that other value -based measures and conventional accounting based measures outperform REVA in predicting value creation. The reason for the failure of REVA is more attention given by 
investors in Iranian stock exchange to conventional accounting measures.Nakhaei et al. (2016) conducted a study in Malaysian Stock Exchange to check the significance of REVA. The results of this study showed that REVA was not a better estimator of stock returns. Thus, the evidenceon the superiority of the performance evaluation criteria is still inconclusive, whereby certain studies indicate better performance of traditional accounting measures in predicting the value of the firms, while other indicate towards EVA or REVA in this regard.

This confusion needs to be resolved in thelocal context of Pakistan and also Refined EVA has not been tested yet in Pakistan. This study makes a contribution by introducing Refined EVA to Pakistani corporate world to predict MAR (Market-Adjusted Returns).A firm's stock performance through MAR has been widely used in the previous studies (Bowen, 1989; Biddle, 1997). This is considered as a better indicator of shareholders' value than just stock returns (Lee \& $\mathrm{Kim}, 2009)$.The reason is that it takes into account the stock returns in comparison to market returns whereas stock returns alone is an absolute measure. Further, due to sectoral considerations, only one sector was chosen to find implications of both traditional and contemporary performance measure for the market value of the firm. Cement sector of Pakistan was chosen in this regard.

This study is being conducted on cement companies listed on Pakistan Stock Exchange for the period 2006 to 2014. The cement industry is indeed an important segment of industrial sector that is rightly considered as a barometer for economic activity. Pakistan cement industry has shown marvelous development since the time of independence. In 1947, Pakistan had inherited only four cement plants with a total capacity of 0.5 million tons per annum whereasfor the period from 2003 to 2008, cement industry of Pakistan had registered an average growth rate of 20\% due to economic boom in the country and high economic growth rate. Pakistan began exporting cement in 2001-02 for utilizing excess capacity.Besides meeting the domestic demand, Pakistan is the fifth largest cement exporter in the world (Afza\& Nazir, 2011).Cement sector stands at third place in the top ten sectors (Pakistan Stock Exchange, 2016). In the recent years, capacity utilization of the cement industry is only 64\% approximately(Afza\& Nazir, 2011). To overcome this problem, cement industry should rethink and focus on infrastructure building to meet the market demand and to maximize profits from its operations. The cement industry is a capital-intensive industry and requires a much bigger commitment of funds to setup a new business and to expand its capacity further. Interested investors necessarily need some useful decision guide.This study shall be helpful to the investors to facilitate their investment decisions. This research shall also provide useful recommendations to the corporate managers in adopting the appropriate performance evaluation basis.

\subsection{Statement of the Problem}

Although accounting measures such as ROA, ROI, NI, EPS have been widely used for business performance measurement (Jacobson, 1987), they have lost their importance with time. Whileseveral studies provide mixed findings on the effectiveness of REVA and EVA as contemporary performance measures. REVA concept is still unknown to a developing economy like Pakistan. From above, a high need is being felt to test REVA effectiveness in Pakistani corporate world.

\subsection{Objectives of the Study}

The objectives of this study are:

- To check the relationship between Refined EVA and MAR

- To investigate if REVA is a better predictor than EVA and other accounting measures in explaining market 
adjusted returns (MAR)

\subsection{Significance of the Study}

This study has empirical significance. This research adds to the existing body of knowledge relating to the debate on the comparative significance of traditional performance measures vs. contemporary performance measures. The study also investigates this phenomenon in the Pakistani context. Pakistan has serious lacking in the development of theory and accumulation of knowledge. The study empirically investigates the predictive power of Refined Economic Value Added (REVA) in explaining the Market Adjusted Returns (MAR) of the corporate sector in an emerging economy, Pakistan.Thus, this evidence will help in building the knowledge in the paradigm of performance evaluation and relevance of accounting performance measures in this regard. The conclusion shall provide guidance tothe corporate sector and local academia to better understand the notions on performance measurement and also would help to design future studies of this domain of the knowledge. Investors, regulators and policy- makers would be able to understand performance dynamics of the corporate sector of Pakistan.

\subsection{Research Question}

Does REVA outperform EVA and traditional accounting measures in explaining MAR?

\subsection{Hypothesis of the Study}

$$
\begin{aligned}
& \mathrm{H}_{0 \mathrm{a}}=\text { There is no relationship between REVA and MAR } \\
& \mathrm{H}_{1 \mathrm{a}}=\text { There is a relationship between REVA and MAR } \\
& \mathrm{H}_{0 \mathrm{~b}}=\text { There is no relationship between EVA and MAR } \\
& \mathrm{H}_{1 \mathrm{~b}}=\text { There is a relationship between EVA and MAR }
\end{aligned}
$$

\subsection{Cement Sector of Pakistan}

Cement sector is one of the oldest and core corporate industrial sectors of Pakistan, which existed before the independence of Pakistan in 1947. There has been an increasing demandfor cement in the local market, and in anticipation of a further increase in demand, firms in the cement sector are considering increasing their production capacity by 2018 . According to the report of JCR-VIS, cement consumption had reduced around the globe in the year 2015. The report also projected a lower growth of the cement consumption around the globe, and the growth was expected to come from the countries of USA, Pakistan, India, Colombia, Nigeria, and Vietnam. Pakistan is $14^{\text {th }}$ largest producer of the cement in the world and is accounted for in the five largest cement exporters.

\subsection{Limitations of the Study}

This study has not taken some value based measures like Created Shareholder Value and cash -based measures like Cash Value Added, Cash Flow Return on Investment. Similarly, instead of MAR, some other measure of wealth creation can be taken into use for further studies. The time period is restricted due to the availability of data.

\subsection{Organization of the Study}

This study is organized into five chapters, details on which are as follows:

- The first chapter introduces the topic, provides background, statement of the problem and significance of the 
study and enlists objectives of this research along with its research questions and hypothesis.

- The second chapter provides an overview of the literature on the comparative significance of the traditional performance measures and contemporary performance measures.

- The third chapter of the study entails research methodology, which specifies the model of the research along with its relative variable description. The details on population, sampling, time frame of study, collection of data and analysis procedure are also provided by the chapter.

- The fourth chapter provides descriptive analysis, correlation analysis and regression analysis of the relative dependent and independent variables of the study.

- The fifth chapter concludes the research by providing an overview of research and its finding and limitations.

\section{LITERATURE REVIEW}

Studies before the early 90s extensively indicate the effectiveness of conventional accounting measures like Return on Equity (ROE), Return on Assets (ROA), Earning per share (EPS), Net income (NI) to measure business performance. In particular, ROI has been widely considered as the most powerful and ultimate performance measure (Reece, 1978). The study carried out by Jacobson (1987) also observed a significant association between ROI and stock returns. The reason is that ROI gives the relationship between profits generated on an investment made in assets.

Despite widespread use of accounting measures, they have been extensively criticized also. According to Harcourt (1965), ROI does not properly relate profits to the investment. Profits are the results of past investment decisions but assets have influence not only on past, present but also on future earnings (Fisher, 1983).Marshall (1890), a famous economist, first talked of the concept of economic profit.However, the concept was applied in the shape of EVA model by Stewart (1991). He proposed that EVA is a better predictor of stock returns than any other traditional performance measures. He argued that EVA reflects only real profit made by a company after considering the cost of all capital used. Previously, other researchers suggested that earnings, without regard to capital invested to produce those earnings, are enough to explain stock return variations. (Byrne, 1996).

Bacidore (1997) introduced Refined Economic Value Added (REVA) and argued that market value of the firm's assets should be used for calculating capital charge instead of the economic book value of assets. Considering market value gives a more realistic value of value added for the creation of shareholder wealth. To test this hypothesis, Bacidore (1997) conducted a study using Stern Stewart performance 1000 database for the period 1982 to 1992. Random selection of 600 firms was made out of 1000 firms and measures like EVA, REVA, Total shareholder return and Risk-adjusted abnormal return for each year were calculated. These calculations were matched against corporate financial data for a same time period. This data was taken from Standard \& Poor's Compustat and The University of Chicago's CRSP databases. Findings showed that EVA performs well in explaining shareholder value creation but REVA was found better predictor than EVA. Moreover, realized returns of top 25 REVA firms for 1988-92 were found higher than those of top 25 EVA firms.

Another study conducted by Farsio(2000) argued that performance measurement using EVA is more relevant for the corporations as it relates the objectives of the company to shareholders' wealth and it also provokes continuous improvement in the management of the corporation. The study also provided that level of the current EVA of the company 
is not that relevant, the thing which matters is the changes in the level of EVA. The study related its results with the companies in well-known stock indices i.e. Standard \& Poor 500 (S\&P 500) and Dow Jones Industrial Average (DJIA).

Rajesh (2012) argued that EVA and MVA as contemporary performance measures are quite effective and are real indicators of the financial performance of the contemporary organization. Using 10 -year data from 2002 to 2011 , the study ranked cement sector companies in India in accordance with their EVA and MVA. The study found that Grasim Cement Company and ACC Limited were the most effective companies in Indian cement sector during the study tenure. These companies were having higher EVA and MVA and were also providing consistent performance in thecontext of stock market returns. The study highlighted the importance of the contemporary performance measures in relation to the explanation of the stock returns of the companies in India.

Arabsalehi(2012) contended to provide empirical evidence on the contemporary performance measures and traditional accounting-based performance measures for the power to explain market value of the firm. Data were pooled from 2001 to 2008 for 115 Irani firms listed in Tehran Stock Exchange. Four contemporary performance measures were used in the study i.e. EVA, REVA, MVA, and SVA, while five traditional accounting- based performance measures were used in the study i.e. EPS, ROA, ROE, return on sale and cash flow from operations. The study rejected the notions of the relevance of contemporary performance measures and provided that ROA and ROE are better predictors of the market value of the firm. Using incremental information content test, the study posited that contemporary performance measures provide only marginal support to the explanation of market value as compared to the traditional measures of performance.

Wood (2000) provided benefits and limitations of the EVA in South African perspective. He argued that EVA provides a single year value that explains the future prospects of the company and firms in this regard should strive to achieve a positive EVA value. The study provides cases of two companies; one from South Africa and one from New Zealand, which implemented concepts relating to EVA. The study highlighted that EVA has both problems and benefits, whereby it provides a more objective measure of performance management and forces managers to be more efficient in their asset and capital utilization. The measure also has certain shortcomings that it does consider qualitative performance aspects of the business. It also is inconsistent with GAAP. It might not be suitable for growth industries. It has yielded inconsistent results with regard to its impact on the stock returns in different studies and it also does not consider the effects of inflation. So, EVA although is a better measure of performance as compared to the traditional financial measures, it still is incomplete and the foundations of performance management are needed to be improved. Lastly, the study referred that the concept is already widespread in use in the corporate sector of South Africa and awareness reading usefulness of the concept is increasing over the time.

Sharma and Kumar (2010) provided a review of the literature on the issues and value of the concept of economic value added (EVA). The study considered a total of 112 studies published during 1994-2008. The documentary analysis indicated that studies conducted in the developed economies found a positive link of EVA with real performance of the organization. Some studies also indicated that consideration of the conventional accounting performance measures also yielded significant results in relation to the stock valuation. While developing countries do not seem to have much of the evidence with regard to the performance and value of EVA. It was further elaborated that the value of the concept has been recognized largely in the developed world, but still. there are controversies relating to the validity and implementation of the concept. However, its usefulness as an information measure to the researchers and managers is deemed established.

Ismail (2011) investigated the ability of the EVA to predict organizational performance in Malaysia. The sample 
was divided into companies having positive EVA and negative EVA.The findings showed a good relationship of EVA and stock returns for a long period of time.Thus, the study rejects the idea of the irrelevance of the EVA with stock returns in Malaysia.

Bayrakdaroglu(2012) provided the evidence of the impact of corporate governance on value -based measures of EVA, MVA, and CVA. Data were collected from 41 companies of the Istanbul Stock Exchange for the period from 1998 to 2007. The study indicated that if CEO is a member of the board, firms' EVA, MVA and CVA increases. Further, variables of ownership concentration and foreign ownership also had a positive impact on EVA, while foreign ownership had a negative impact on MVA and board size was an insignificant predictor of all of the performance measures of the company. The study indicates towards the trend of using contemporary performance measures as a proxy of performance and ignoring traditional performance measures of EPS, ROA and ROE.

Lee (2009) compared the traditional performance measures of ROA, ROE, and cash flow from operations with EVA and REVA in context of their explanatory power in the hospitality industry. An extensive data relating to 353 companies for 20 years from 1985 to 2004.The study indicated that REVA outperformed all other measures of the performance in the hospitalityindustry.Hospitality industry was represented by hotel companies, restaurants and casino and the study also considered these three industries separately. In overall sample REVA, EVA, MVA, and ROE were deemed significant, whereas REVA was the strongest predictor of stock returns. In hotel sample, EVA, MVA and ROA were found significant, whereas ROA was the strongest predictor of stock returns. In restaurant sample, REVA and MVA were significant, whereas MVA was strongest predictor and lastly, EVA, REVA, MVA and ROA were found significant, whereas REVA was strongest predictor of stock returns. This indicates that performance measures could have different implications for different industries.

Laing and Dunbar (2015) provided longitudinal evidence on the relevance of performance measures like EVA, EPS, ROA and ROE for their significance and power to exhibit informational content. The study found that EPS was astronger predictor of the stock return in the banking sector of Australia, while EVA exhibited a significant and strong incremental informational content with regard to the prediction of stock returns. The study implies that traditional performance measures still have power with regard to the stock price prediction and change in EVA could signify the changes in the long run performance of the company.

Alipour and Pejman (2015) investigated the comparative significance of EVA with six traditional accounting performance measures by taking the sample of 450 observations from the companies listed in Tehran Stock Exchange (TSE). Using pooled and panel data estimation techniques, this study provides that EVA does not exhibit the stronger capability of stock return prediction as compared to the traditional performance measures. The measures of return on sales and return on assets were found to have a relatively stronger impact on the stock returns of the companies. This study rejected the modern implications of EVA and reestablished the significance of traditional performance measures.

Hall (2013) provided the evidence on the different performance measures with regard to their ability to predict value creation in different industries. The study found evidence of different implications of performance measures for different sectors. Further, the importance of economic indicators was found more pronounced as compared to the importance of the traditional accounting-based measures as economic indicators are considered more information rich.

Alomoush and Al-Shubiri (2012) also studied the impact of various performance measures like ROA, ROE, EVA 
and MVA on the stock return in Jordan. Considering a sample of 54 companies, the study found that variables of ROA and ROE have significant implications for the stock return and same is the case with the contemporary measures of EVA and MVA. The study argued that users of financial statements and other stakeholders should use both conventional and contemporary performance indicators for the better assessment of the real long- term performance of the company.

De Wet (2005) reported that executive compensation has been misaligned in many companies around South Africa and availability of new performance measures like EVA and MVA has provided an opportunity to such companies as these companies could structure a compensation plan, which would be aligned to the shareholders' wealth maximization criterion. The study utilized a comparative approach to test the implications of EVA vs. traditional performance measures for executive compensation. The findings of the study indicated that EVA and MVA significantly predicted executive compensation but this explanatory power was stronger considering ROA \& ROE, implying that organizations still are utilizing traditional performance measures in South Africa. The study concluded that South African companies should shift their focus towards contemporary performance measures like EVA and MVA for better alignment of their executive compensation plans to the value maximization principle.

Panigrahi (2014) explained that EVA has evolved as a relevant aspect of organizational performance, which is proposed to have significant implication for the value of the organization. This study in this regard tries to relate EVA and MVAfor the companies listed in Malaysia Stock Exchange. By considering the data of 11 years from 2003 to 2013 , this study found a negative impact of EVA on MVA. This study has broader implications in terms of capital investment.

Pourali(2013) sought to relate MVA with REVA and other conventional accounting performance indicators. Measures of ROA and REVA were proved to be the most significant measures of the market value of a firm, while variables of ROE and EPS also had a significant correlation with the market value of the organization. The study does not reject the significance of the traditional accounting measures i.e. EPS, ROE and ROA along with the contemporary performance indicators of EVA and REVA.

A comparative study was conducted by Fayed and Dubey (2016), who compared the relative impact of EVA momentum and traditional accounting measures on the shareholders' wealth creation. The data for the study was collected from the companies of UAE, for the period from 2008 to 2013. The study confirmed the superiority of EVA momentum over other traditional performance measures and supported the view that EVA fluctuations have the ability to explain longterm performance of the corporations in UAE.

Shah, Haldar, and Rao (2015) embarked on the value of EVA as a performance measurement and management tool. The study elaborated that EVA has more informational content as compared to earning based measures of firm performance. Implementation of the concept has the ability to reduce cost and enable employees to understand the implications and context of value creation for organization. The EVA was also argued to have a positive association with the dependent variable i.e.Market Value- added and also exhibit predictability power.

Owusu-Antwi(2015) also sought to determine the performance of banks adopting EVA approach. The study made a point that financial sector of Ghana was suffering from inefficiencies and other structural problems, which were the major cause of lower profitability of the banks. Using data set of 1988 to 2011, this study measured the performance prospects of the banks by comparing the accounting performance measure of ROA and EVA. It was found that EVA was a better measure of performance as compared to ROA. The study implied that using EVA as a performance measure and 
focusing on it could have the potential to sustain banking sector performance of Ghana.

Dunbar (2013) thematic bibliography of EVA related studies by considering 49 articles published by the mid of 2013. The study indicated that most of the research on EVA considered EVA theory \& model development and role of EVA in the measurement of organizational wealth. Some studies also considered the value of EVA as a tool to appraise investment projects and lastly few studies were traced on a comparison of EVA with other performance models. The study concluded that there are conflicting results on the superiority of EVA over other traditional performance measures.

Ismail (2014) sought to establish the impact of modern vs. traditional performance measurement instruments on corporate firms of Pakistan. The study considered EVA and MVA as contemporary performance measures and EPS, ROCE, OCF, ROA, ROE, NI, ROI , and NOPAT as traditional performance measures. Data were collected from 35 firms of 7 sectors of Pakistan for two years (2010-2011). The study found that only ROE explained MVA for the year 2011 only and all of the remaining variables did not exhibit any explanatory power with regard to MVA. The study indicated towards inability of both traditional and contemporary performance measures to explain long- term performance prospects of the corporations in Pakistan.

Bluszcz(2016) provided empirical evidence on the factors affecting economic value added of mining companies, whereby EVA ultimately led towards the enhanced market value of the firm. The study found evidence that EVA was related to the capital investments, economic spread, whereby economic spread is depicted by the weighted average cost of capital and return on capital invested. The study suggested conducting a detailed analysis of EVA for understanding implications of the concept for a market value of the firm.

Hall (2016) conducted a study on the premise of conflicting evidence on the relationship of different performance measures and market value of the firm. The study estimated results for different industries and found that market value added was a better predictor of the value of the firm. Further, traditional accounting - based measures depicted a superior explanatory power as compared to EVA and ROCE. Further, it was also found that explanatory power of variables differed between different industries. Industries like industrial goods showed the better explanatory power of both traditional and contemporary measures, while only traditional measures of EPS and ROA explained market value of firms in food and beverage industry.

Nakhaei et al. (2016) contended to estimate the comparative significance of traditional accounting -based measures in relation to the significance of contemporary value - based measures in relation to the stock returns of the firms listed in Malaysian Stock Exchange. The study used data from 395 firms from 2002 to 2011 and found that REVA did not have better significance in explaining stock return as compared to net profits. REVA although provided a significant relationship with the stock return, its strength of the relationship was weaker as compared to net income and NOPAT. Further, EPS yielded an insignificant impact on the stock return.

Overall, a literature review of the study provides mixedevidence. Certain studies have demonstrated positive implications of REVA, EVA, and related measures on stock returns and long-term performance of the corporation, while others have proved the value of traditional measures of performance in this regard. Certain studies disregard the value of all of the traditional and contemporary measures of the firm performance. Sector-specific differences with regard to the ability of performance measures to explain stock returns were also found. 


\section{METHODOLOGY}

\subsection{Research Model}

The purpose of the study is to compare the explanatory power and significance of traditional accounting performance measures i.e. ROA, ROE and EPS with contemporary performance measures i.e. EVA and REVA. Following is the research model specified in this regard:

$$
M A R_{i t}=\alpha+\beta_{1}\left(R E V A_{i t}\right)+\beta_{2}\left(E V A_{i t}\right)+\beta_{3}\left(R O E_{i t}\right)+\beta_{4}\left(R O A_{i t}\right)+\beta_{5}\left(E P S_{i t}\right)+\varepsilon_{i t}
$$

Where,

$\alpha=$ Constant term

$\beta_{1}-\beta_{5}=$ Beta Coefficients

MAR $=$ Market Adjusted Return

REVA $=$ Refined Economic Value Added

ROE $=$ Return on Equity

$\mathrm{ROA}=$ Return on Assets

EPS $=$ Earningsper Share

$\varepsilon=$ Error term

\subsection{Variable Definition}

As the model of the study indicates, market adjusted return (MAR) is the dependent variable of the study and refined economic value added (REVA), economic value added (EVA), return on assets (ROA), return on equity (ROE) and earning per share (EPS) are considered as independent variables of the study. This part of the methodology defines each of these variables and also provides measurement schemes for these variables.

\subsubsection{Market Adjusted Return (MAR)}

This measure provides the abnormal returns above or below the normal market returns. Thus, market returns are considered as benchmark and proxy of the normal returns and stock returns above or under that benchmark are taken as a true depiction of the firm performance. Following Biddle et al. (1997) and Lee and Kim (2009), this study calculates market adjusted return by subtracting 12 month's market returns from 12 month's stock returns. A twelve-month period is considered to account for the incorporation of the financial report's information into the stock price in an effective manner. Followingis the calculation formula for the variable:

MAR $=$ Firm's stock returns - Market returns

\subsubsection{Economic Value Added (EVA)}

EVA is considered a contemporary performance measure, which could be calculated using the financial statements of the firm. The measure in that way is able to relate towards the true value of the organization. This variable is measured by the following formula:

EVA $=$ Net Operating Profits after Tax $-($ WACC $*$ Book value of Capital $)$ 


\subsubsection{Refined Economic Value Added (REVA)}

A new version of economic value added was introduced by Bacidoreetal.(1997), who proposed that cost of capital should not be calculated on the book values, rather market values should be considered in this regard as market values provide true depiction of the capital employed by the organization and also cost of the capital is levied on the firm in accordance with the market values of the firm's capital. Following is the calculation formula of REVA:

REVA $=$ Net Operating Profits after Tax $-($ WACC $*$ Market value of Capital $)$

\subsubsection{Earning Per Share}

Earning per share, a traditional measure of performance, is still widely used by the users of financial statements. This measure considers the performance of the organization as per unit of investment. Some studies indicate that it has positive a significant impact on the stock returns(Kim, 2006; Yaqub, 2015). The traditional measurement of the EPS was used for the study, which is as under:

EPS $=$ Net profit of the firm / Number of outstanding shares

\subsubsection{Return on Assets (ROA)}

It is the percentage of Net Income relative to the total asset a firm employs. In the Du Pont analysis, ROA is broken down into the product of Net Profit Margin and Total Asset Turnover (Wirawan, 2011). Following Lee and Kim (2009), ROA was measured using the following formula:

$\mathrm{ROA}=($ Net Profit $/$ Total Assets $) * 100$

\subsubsection{Return on Equity (ROE)}

Return on Equity is calculated by taking the profit after tax and preference dividends of a given year and dividing it by the book value of equity (ordinary shares) at the beginning of the year. Average equity can also be used. Equity would consist of issued ordinary share capital plus the share premium and reserves (De Wet, 2007).

$$
\mathrm{ROE}=(\text { Profit after tax } \& \text { preference dividend / Equity }) * 100
$$

\subsection{Population and Sampling Design}

20 companies are listed in the cement sector of Pakistan (SBP, 2014), which constitute population for the study. All of these companies were considered for data collection and data was collected from 19 of these companies for the period of 9 years from 2006 to 2014. One company was excluded from final sample as this company did not have data for whole of the study period. Thus, consideration of whole of the population in the sample improves the generalizability of the study. Data has been collected from websites of State Bank of Pakistan and Pakistan Stock Exchange.

\section{DATA ANALYSIS}

\subsection{Descriptive Analysis}

Table 1: Descriptive Statistics

\begin{tabular}{|l|c|c|c|c|c|c|}
\hline & MAR & EPS & EVA & REVA & ROA & ROE \\
\hline Mean & $0.02 \%$ & 3.00 & 689985.6 & 574942.2 & $3.47 \%$ & $1.52 \%$ \\
\hline Median & $-0.05 \%$ & 0.47 & 68445.6 & 82474.7 & $1.37 \%$ & $5.36 \%$ \\
\hline Maximum & $4.30 \%$ & 38.86 & 9624372.0 & 7397460.0 & $43.97 \%$ & $104.99 \%$ \\
\hline Minimum & $-0.51 \%$ & -12.83 & -2412613.0 & -2137091.0 & $-28.21 \%$ & $-469.94 \%$ \\
\hline
\end{tabular}




\begin{tabular}{|l|c|c|c|c|c|c|}
\hline \multicolumn{7}{|c|}{ Table 1: Contd., } \\
\hline Std. Dev. & $0.41 \%$ & 8.00 & 1860611.0 & 1632355.0 & $13.33 \%$ & $57.14 \%$ \\
\hline Skewness & 7.13 & 1.55 & 1.96 & 1.73 & 0.62 & -4.62 \\
\hline Kurtosis & 72.41 & 6.28 & 7.92 & 6.42 & 3.50 & 34.22 \\
\hline Jarque-Bera & 35773.1 & 144.86 & 282.30 & 168.55 & 12.67 & 7550.69 \\
\hline Probability & 0 & 0 & 0 & 0 & 0 & 0 \\
\hline Sum & $3 \%$ & 513.66 & $1.18 \mathrm{E}+08$ & 98315111 & $593.3 \%$ & $260.38 \%$ \\
\hline Sum Sq. Dev. & 0.00 & 10873.7 & $5.89 \mathrm{E}+14$ & $4.53 \mathrm{E}+14$ & 30223.8 & 554965 \\
\hline Observations & 171 & 171 & 171 & 171 & 171 & 171 \\
\hline
\end{tabular}

Market -adjusted return (MAR) was considered as dependent variable of the study, which yielded a mean value of $0.02 \%$ along with a standard deviation of $0.41 \%$. The minimum value for this variable was recorded to be $-0.51 \%$ and the maximum value were recorded as 4.3\%.Earnings per share (EPS) was the first independent variable of the study, which yielded a mean value of 3 and a standard deviation of 8 . The minimum value for the variable was -12.38 and the maximum value was 38.86. Economic value added (EVA) was next independent variable of the study, which had a mean value of 689985.6 along with a standard deviation of 1860611 . The minimum value for EVA was recorded to be -2412613 and the maximum value was recorded to be 9624372. Refined economic value added was next independent variable of the study. This variable provided a mean value of 574942.2 and a standard deviation of 1632355.The minimum value of REVA was recorded to be -2137091 , while the maximum value for the variable was 7397460 . Return on assets was the next independent variable of the study, which yielded a mean value of $3.47 \%$ along with the standard deviation of $13.33 \%$. The minimum ROA in the sample was found to be $-28.21 \%$ and maximum ROA was found to be $43.97 \%$. Last independent variable of the study was return on equity (ROE), which had a mean value of $1.52 \%$,standard deviation of $57.14 \%$ along with a minimum value of $-469.94 \%$ and the maximum value of $104.99 \%$.

A total of 171 observations were considered for the study. Descriptive analysis indicates that there is much variation in the data set relating to the variable of the study and the data seems quite suitable for the study.

\subsection{Correlation Analysis}

Table 2: Correlation Matrix

\begin{tabular}{|l|c|c|c|c|c|}
\hline & MAR & EPS & EVA & REVA & ROA \\
\hline EPS & 0.03 & & & & \\
\hline EVA & 0.15 & 0.73 & & & \\
\hline REVA & 0.11 & 0.70 & 0.96 & & \\
\hline ROA & 0.11 & 0.79 & 0.55 & 0.55 & \\
\hline ROE & 0.09 & 0.41 & 0.30 & 0.31 & 0.57 \\
\hline
\end{tabular}

Table 2 provides correlation coefficient for the interrelationships of the study. Firstly, all independent variables depicted a positive relationship with dependent variable ofmarket-adjusted return and the relationship was quite weak as indicated by a lower correlation coefficient $(\mathrm{r}<0.3)$. Secondly, many independent variables considered in the studydepicted indication of a strong correlation. The strongest correlation in this regard was provided by the variables of economic value added (EVA) and refined economic value added (REVA) i.e. $\mathrm{r}=0.96$. This strong correlation could be expected as EVA and REVA arealmost one and the same thing. Further, EPS also had a strong correlation with EVA, REVA, and ROA (r >0.7). EVA and REVA have a moderate correlation with ROA and weak correlation with ROE. Lastly, ROA had a moderate correlation with ROE. The correlation analysis indicates that there could be problems of multicollinearity between independent variables considered for the study. Gujrati (2009) explained that correlation coefficient valuing above 
0.8 indicates severe problems of multicollinearity and under such situations, one of the multicollinear variables should be excluded from the model to deal with the problem. This study has specific purpose to understand the relative significance of the traditional and contemporary performance measures in relation to the shareholders' value of the firm and all of the independent variables of the study relate to the performance aspect of the firm.Therefore, different performance measures of the firm are definitely related to each other to some extent. The subsequent part of the analysis provides multicollinearity diagnostic tests for the variables included in the study. This procedure is adopted following Lee and Kim (2009), who utilized VIF test in such situation, whereby a VIF value of above 10 is considered an indication of the problem of multicollinearity among independent variables (Ott\&Longnecker, 2001).

\subsection{Multicollinearity Diagnostic Test}

Correlation analysis of the study provided in the previous section of the analysis indicates that there exists strong correlation among different independent variables of the study. In order to probe this problem further, this section of the analysis provides VIF test of multicollinearity diagnosis. Thus, VIF test was conducted using E-Views for the detection of the problem of multicollinearity.

Table 3 provides the variance inflation factors (VIF) for all of the independent variables of the study, whereby VIF value for two variables exceeded the threshold value of 10, indicating severe problem of multicollinearity. These two variables are economic value added (EVA) having VIF value of 17.18 and refined economic value added (REVA) having VIF value of 15.09.All remaining independent variables i.e. EPS, ROA and ROE yielded VIF values lower than the threshold of 10

Table 3: Multicollinearity Diagnostic Test - VIF (All Independent Variables)

\begin{tabular}{|l|c|c|c|}
\hline Variable & Coefficient Variance & Un-Centered VIF & Centered VIF \\
\hline C & $1.09 \mathrm{E}-07$ & 1.18 & NA \\
\hline EVA & $4.05 \mathrm{E}-19$ & 17.18 & 15.09 \\
\hline REVA & $4.80 \mathrm{E}-19$ & 15.48 & 13.76 \\
\hline EPS & $5.82 \mathrm{E}-09$ & 4.57 & 4.00 \\
\hline ROA & $1.72 \mathrm{E}-09$ & 3.52 & 3.29 \\
\hline ROE & $4.23 \mathrm{E}-11$ & 1.49 & 1.48 \\
\hline
\end{tabular}

Thus, two variables i.e. EVA and REVA were found to have multicollinearity problem in this model. This high correlation between these two variables is logical as both of these variables have same notions and one is refined version of the other. The objective of the study was to relate REVA with the sharholders' value of the organization and compare this in relation to other performance measures. Thus, the variable of EVA was dropped from the model in order to control the problem of multicollinearity. Further, as REVA is a refined version of EVA, so there is no possibility of the specification bias as well.

In order to check whether the problem of multicollinearity had been removed after the exclusion of EVA from the model, VIF test was again conducted after exclusion of EVA from the model as the independent variable. Table 4.provides VIF multicollinearity diagnostic test results in this regard. The table indicates that after exclusion of EVA from the model, no VIF value exceeded the threshold value of 10, which implies that exclusion of EVA had solved the problem of multicollinearity in an effective manner and now regression analysis could be proceeded with, so that the importance of the performance measures could be established in relation to the market value of the firms in cement sector of Pakistan. 
Table 4: Multicollinearity Diagnostic Test - VIF (After EVA Exclusion)

\begin{tabular}{|l|c|c|c|}
\hline Variable & Coefficient Variance & Un-Centered VIF & Centered VIF \\
\hline C & $1.14 \mathrm{E}-07$ & 1.18 & NA \\
\hline REVA & $7.16 \mathrm{E}-20$ & 2.20 & 1.95 \\
\hline EPS & $5.53 \mathrm{E}-09$ & 4.13 & 3.62 \\
\hline ROA & $1.78 \mathrm{E}-09$ & 3.47 & 3.24 \\
\hline ROE & $4.44 \mathrm{E}-11$ & 1.48 & 1.48 \\
\hline
\end{tabular}

\subsection{Regression Analysis}

The variable of EVA was excluded from the combined analysis, as this variable hada strong correlation with REVA leading towards the problem of multicollinearity in the model. Regression analysis of the study was conducted in two steps, whereby firstly a combined regression considering all independent i.e. variables REVA, EPS, ROA ,and ROE was conducted and after that, five separate regressions, considering the individual impact of each of the five independent variables, were conducted. The aim of this procedure is to compare the relative explanatory power of each of the five performance measures with reference to the market-adjusted returns (MAR) of the firms listed in the cement sector of Pakistan Stock Market.

\subsubsection{Overall Regression}

This part of the analysis provides regression estimation considering MAR as dependent variable and REVA, EPS, ROA and ROE as independent variables of the study. Table 5 provides regression estimation results in this regard:

F-statistics of the model is 1.41 , which is quite low and indicates that the model is not a good fit and estimation has limited explanatory power. The R-squared of the model is also lower i.e. 0.03 , indicating that only $3 \%$ variation in the market adjusted return (MAR) was predicted by the variables included in the model. Durbin Watson statistics of the estimation was 1.97 , which is near the standard value of 2 , indicating that no problem of autocorrelation was prevalent in the regression estimation. Overall, the regression estimation provided an indication that the traditional measures of profitability along with REVA are unable to predict market adjusted returns in the cement industry of Pakistan.

Table 5: Regression Output (Overall)

\begin{tabular}{|l|c|c|c|c|}
\hline Variable & Coefficient & Std. Error & t-Statistic & Prob. \\
\hline C & $1.13 \mathrm{E}-04$ & $3.38 \mathrm{E}-04$ & 0.33 & 0.739 \\
\hline REVA & $3.96 \mathrm{E}-10$ & $2.67 \mathrm{E}-10$ & 1.48 & 0.140 \\
\hline EPS & $-1.24 \mathrm{E}-04$ & $7.43 \mathrm{E}-05$ & -1.67 & 0.096 \\
\hline ROA & $5.96 \mathrm{E}-05$ & $4.22 \mathrm{E}-05$ & 1.41 & 0.160 \\
\hline ROE & $2.54 \mathrm{E}-06$ & $6.66 \mathrm{E}-06$ & 0.38 & 0.703 \\
\hline R-squared & 0.03 & Mean dependent var & 0.00 \\
\hline Adjusted R-squared & 0.01 & S.D. dependent var & 0.00 \\
\hline S.E. of regression & 0.00 & Akaike info criterion & -8.14 \\
\hline Sum squared resid & 0.00 & Schwarz criterion & -8.05 \\
\hline Log likelihood & 700.91 & Hannan-Quinn criter. & -8.10 \\
\hline F-statistic & 1.41 & Durbin-Watson stat & 1.97 \\
\hline Prob(F-statistic) & 0.23 & \multicolumn{3}{|l}{} \\
\hline
\end{tabular}

Considering the individual relationship of the performance measures with market adjusted returns, it was found that all variables included in the model i.e. REVA, EPS, ROA and ROE yielded an insignificant impact on the MAR. The Impact of EPS was relatively strong but insignificant and negative. The estimation provides inconclusive evidence with regard to the impact of the performance measures on market performance of the companies in cement sector of Pakistan. 
Thus, five individual regressions were conducted to assess individual impact of the five performance measures on the market performance of the cement sector firms in Pakistan.

\subsubsection{Single Variable Regressions}

This part of the analysis provides single variable regressions for the impact of performance measures on the market performance of the cement sector firms in Pakistan. Five independent variables i.e. REVA, EVA, EPS, ROA ,and ROE were regressed with the dependent variable of MAR in separate regressions. Table 6 to table 10 provides estimation results of these regressions.

Table 6 provides regression estimation results for the impact of EVA on MAR. The R-Squared of the model was estimated to be 0.02 , indicating that $2 \%$ variation in the market adjusted returns (MAR) was explained by economic value added (EVA). F-statistics of the model was estimated to be 3.94 indicating that the model estimated is a good fit at $5 \%$ level of significance. Further, a 2.04 value of Durbin-Watson test indicates that no problem of auto-correlation existed in the estimation. EVA yielded a positive and significant impact on MAR as indicated by a positive beta of 3.32E-10 and a tstatistics of 1.99. The relationship was significant at $5 \%$ level of significance. Thus, EVA was found to have explanatory power with regard to its impact on MAR. Table 7 provides estimation results on the impact of refined economic value added (REVA) on market adjusted returns (MAR). The estimation yielded an R-Squared value of 0.01, which indicated that only $1 \%$ variation in the MAR could be explained by REVA. Further, F-Statistics of 1.92 for the model deemed the regression estimation model to be poorly fitted. A 2.03 value for Durbin Watson, however, indicated that there were no traces of the autocorrelation in the estimation. REVA although yielded a positive impact on MAR $($ Beta $=2.66 \mathrm{E}-10)$, but this impact was deemed insignificant by a t-statistics of 1.38. Thus, REVA was found to have insignificant implications and weak explanatory power for MAR in the cement sector of Pakistan.

Table 6: Regression Output (Impact of EVA on MAR)

\begin{tabular}{|l|l|l|l|l|}
\hline Variable & Coefficient & Std. Error & t-Statistic & Prob \\
\hline C & $-5.15 \mathrm{E}-05$ & 0.000331 & -0.16 & 0.877 \\
\hline EVA & $3.32 \mathrm{E}-10$ & $1.67 \mathrm{E}-10$ & 1.99 & 0.049 \\
\hline R-squared & 0.02 & \multicolumn{2}{|l|}{ Mean dependent var } & 0.00 \\
\hline Adjusted R-squared & 0.02 & \multicolumn{2}{|l|}{ S.D. dependent var } & 0.00 \\
\hline S.E. of regression & 0.00 & \multicolumn{2}{|l|}{ Akaike info criterion } & -8.16 \\
\hline Sum squared resid & 0.00 & Schwarz criterion & -8.13 \\
\hline Log likelihood & 700.03 & Hannan-Quinn criter. & -8.15 \\
\hline F-statistic & 3.94 & Durbin-Watson stat & 2.04 \\
\hline Prob(F-statistic) & 0.049 & & & \\
\hline
\end{tabular}

Third regression of the section as provided by table 8 estimates the impact of earning per share (EPS) on market adjusted return (MAR). R-squared was found to be 0.00 and F-statistics of 0.21 further indicated towards inability of EPS to explain MAR. The estimation model was not a good fit but Durbin Watson statistics of 2.04 indicated no presence of the problem of autocorrelation in the estimation. EPS although was found to have a positive association $($ Beta $=1.79 \mathrm{E}-05)$ with MAR, this association was insignificant ( $\mathrm{t}$-statistics $=0.45$ ). Thus, EPS also was unable to explain MAR to any significant extent. 
Table 7: Regression Output (Impact of REVA on MAR)

\begin{tabular}{|l|c|l|c|c|}
\hline \multicolumn{1}{|c|}{ Variable } & Coefficient & Std. Error & t-Statistic & Prob. \\
\hline C & $2.50 \mathrm{E}-05$ & $3.31 \mathrm{E}-04$ & 0.08 & 0.94 \\
\hline REVA & $2.66 \mathrm{E}-10$ & $1.92 \mathrm{E}-10$ & 1.38 & 0.17 \\
\hline R-squared & 0.01 & \multicolumn{2}{|l|}{ Mean dependent var } & 0.00 \\
\hline Adjusted R-squared & 0.01 & \multicolumn{2}{l|}{ S.D. dependent var } & 0.00 \\
\hline S.E. of regression & 0.00 & Akaike info criterion & -8.15 \\
\hline Sum squared resid & 0.00 & Schwarz criterion & -8.12 \\
\hline Log likelihood & 699.02 & Hannan-Quinn criter. & -8.14 \\
\hline F-statistic & 1.92 & Durbin-Watson stat & 2.03 \\
\hline Prob(F-statistic) & 0.17 & \multicolumn{2}{|}{} \\
\hline
\end{tabular}

Fourth regression of the analysis is provided in table 9, which estimates the impact of return on assets (ROA) on market adjusted return (MAR) in cement sector of Pakistan. F-Statistics of the model was found to be 2.05, which indicated that model is not a good fit. Further, R-squared of the model is also quite low at 0.01 , indicating a lowexplanatory power of the ROA for MAR. Furthermore, ROA was found to have a positive association with the MAR (Beta $=3.36 \mathrm{E}-05$, but this association was found insignificant ( $\mathrm{t}$-statistics $=1.43)$. Thus, ROA was also found incapable to explain MAR in the cement industry of Pakistan.

Table 8: Regression Output (Impact of EPS on MAR)

\begin{tabular}{|l|c|c|c|c|}
\hline \multicolumn{1}{|c|}{ Variable } & Coefficient & Std. Error & t-Statistic & Prob. \\
\hline C & $1.24 \mathrm{E}-04$ & $3.35 \mathrm{E}-04$ & 0.37 & 0.71 \\
\hline EPS & $1.79 \mathrm{E}-05$ & $3.94 \mathrm{E}-05$ & 0.45 & 0.65 \\
\hline R-squared & 0.00 & \multicolumn{2}{|c|}{ Mean dependent var } & 0.00 \\
\hline Adjusted R-squared & 0.00 & \multicolumn{2}{l|}{ S.D. dependent var } & 0.00 \\
\hline S.E. of regression & 0.00 & \multicolumn{2}{l|}{ Akaike info criterion } & -8.14 \\
\hline Sum squared resid & 0.00 & Schwarz criterion & -8.11 \\
\hline Log likelihood & 698.16 & Hannan-Quinn criter. & -8.13 \\
\hline F-statistic & 0.21 & Durbin-Watson stat & 2.04 \\
\hline Prob(F-statistic) & 0.65 & \multicolumn{3}{|}{} \\
\hline
\end{tabular}

Table 9: Regression Output (Impact of ROA on MAR)

\begin{tabular}{|l|c|c|c|c|}
\hline \multicolumn{1}{|c|}{ Variable } & Coefficient & Std. Error & t-Statistic & Prob. \\
\hline C & $6.11 \mathrm{E}-05$ & $3.23 \mathrm{E}-04$ & 0.19 & 0.85 \\
\hline ROA & $3.36 \mathrm{E}-05$ & $2.35 \mathrm{E}-05$ & 1.43 & 0.15 \\
\hline R-squared & 0.01 & \multicolumn{2}{|c|}{ Mean dependent var } & 0.00 \\
\hline Adjusted R-squared & 0.01 & \multicolumn{2}{c|}{ S.D. dependent var } & 0.00 \\
\hline S.E. of regression & 0.00 & \multicolumn{2}{l|}{ Akaike info criterion } & -8.15 \\
\hline Sum squared resid & 0.00 & Schwarz criterion & -8.12 \\
\hline Log likelihood & 699.09 & Hannan-Quinn criter. & -8.14 \\
\hline F-statistic & 2.05 & Durbin-Watson stat & 2.04 \\
\hline Prob(F-statistic) & 0.15 & \multicolumn{2}{|l}{} \\
\hline
\end{tabular}

Table 10: Regression Output (Impact of ROE on MAR)

\begin{tabular}{|l|c|l|c|c|}
\hline \multicolumn{1}{|c|}{ Variable } & Coefficient & Std. Error & t-Statistic & Prob. \\
\hline C & $1.67 \mathrm{E}-04$ & $3.13 \mathrm{E}-04$ & 0.54 & 0.59 \\
\hline ROE & $6.74 \mathrm{E}-06$ & $5.49 \mathrm{E}-06$ & 1.23 & 0.22 \\
\hline R-squared & 0.01 & \multicolumn{2}{|l|}{ Mean dependent var } & 0.00 \\
\hline Adjusted R-squared & 0.00 & \multicolumn{2}{l|}{ S.D. dependent var } & 0.00 \\
\hline S.E. of regression & 0.00 & Akaike info criterion & -8.15 \\
\hline Sum squared resid & 0.00 & Schwarz criterion & -8.11 \\
\hline Log likelihood & 698.82 & \multicolumn{2}{l}{ Hannan-Quinn criter. } & -8.13 \\
\hline
\end{tabular}




\begin{tabular}{|l|c|l|l|}
\hline \multicolumn{5}{|c|}{ Table 10: Contd., } \\
\hline F-statistic & 1.51 & Durbin-Watson stat & 2.06 \\
\hline Prob(F-statistic) & 0.22 & & \\
\hline
\end{tabular}

Lastly, table 10 provides last regression estimation of the study, whereby the impact of return on equity (ROE) is established with reference to market adjusted return (MAR). F-statistics of the estimation was found to be 1.51, which again indicated that the model is not a good fit. R-Squared of the model is also lower at 0.01, which again indicates towards a lower explanatory power of ROE for MAR. A 2.06 value of Durbin Watson test indicates that there exists no problem of autocorrelation in the estimation. The impact of ROE for MAR was again found positive $(\mathrm{Beta}=6.74 \mathrm{E}-06)$ but insignificant ( $\mathrm{t}$-statistics $=1.23$ ), Thus, overall ROE was also not able to explain MAR to any significant extent.

\subsection{Discussions}

The study found the evidence that simple economic value added (EVA) measure outperformed traditional accounting measuresof profit i.e. earnings per share (EPS), return on assets (ROA) and return on equity (ROE) in predicting market adjusted returns (MAR) in cement sector of Pakistan. It even depicted more explanatory power as compared to refined economic value added (REVA). Table 11 provides a summary of the estimation results for the regression estimations performed in the study, whereby both in overall regression and individual variable regressions, only measure of EVA was found significant. This clearly indicates that EVA has better ability to depict true performance of the organization in the cement sector of Pakistan. Traditional accounting measures of EPS, ROA and ROE failed to have a significant relationship with the market performance of the firms in the sector. Thus, the conception of Stewart (1991) on the measurement of the profits also holds true to date. Traditional accounting measures of performance fail to account for the future prospects of the company and just consider the past performance of the company. These profit measures, on the other hand, are based on the 'accounting profits', which could be manipulated or window dressed to make these look like more favorable. So, reliance on the accounting profit and their measures could be a mistake. EVA ,on the other hand, provides an indication of the true value of the company, whereby the cost of capital is also deducted from the net profit after tax. The explanatory power of EVA, however, was lower (only 3\%), but it yielded significant implications for the market return of the organization.

Table 11: Summary of Results

\begin{tabular}{|l|l|l|}
\hline $\begin{array}{c}\text { Performance } \\
\text { Measure }\end{array}$ & $\begin{array}{c}\text { Overall } \\
\text { Regression }\end{array}$ & $\begin{array}{c}\text { Individual } \\
\text { Regression }\end{array}$ \\
\hline EVA & - & Positive** \\
\hline REVA & Positive & Positive \\
\hline EPS & Negative & Positive \\
\hline ROA & Positive & Positive \\
\hline ROE & Positive & Positive \\
\hline
\end{tabular}

** Significant at $5 \%$ level of significance.

\section{CONCLUSIONS}

The first part of this chapter summarizesthe main findings of the study.After that, implications of the study and recommendations are provided and in the last, limitations of the current research are highlighted and directions for the future research are provided. 


\subsection{CONCLUSIONS}

This study considered both traditional and contemporary measures of the performance of the cement sector. The findings of the study indicate that economic value added (EVA) so far, is the best performance measure as this was the only variable which yielded a significant impact on market adjusted returns (MAR) of the cement sector of Pakistan. All other performance measures including refined economic value added (REVA) yielded an insignificant impact on the market adjusted returns (MAR) of the cement sector of Pakistan. Thus, investors should understand and consider the performance measure of economic value added and value should be given to the companies, which have higher economic value added (EVA) in cement industry of Pakistan. A potential problem in this regard is that the economic value added (EVA) exhibited a limited explanatory power with regard to the market adjusted returns (MAR). Although this was also the case in the previous studies (Lee\& Kim, 2009), this implies that there are other important explanatory factors with regard to MAR and determination of MAR requires further exploration.

\subsection{IMPLICATIONS \& RECOMMENDATIONS}

This study documents the relevance of economic value added (EVA) and the irrelevance of the traditional performance measures in the context of explaining market-adjusted returns (MAR) in cement industry of Pakistan. This leads towards the following recommendations for the investors and firms of the sector:

- Economic value added is established as a significant predictor of the market-adjusted returns of the organizations in the cement sector of Pakistan, which implies that REVA and traditional measures of the performance lack the ability to relate to the true performance of the organization. This implies that both investors and organizations should consider the economic value added over REVA and other traditional performance measures of the organization.

- Although EVA is found to have a significant relationship with MAR, but the explanatory power of this measure is weak.This implies that there are other significant predictors of MAR, which should be explored and evaluated. Investors and firms should not consider EVA as thefinal performance measure of a firm's value.

- There is also a need to educate the firms and investors on the value of contemporary performance measures like EVA, and it should be emphasized that utilization of traditional measures of the performance should be avoided.

- Firms need to provide EVA-related calculations and measurement schemes in the annual reports so that both investors and regulators are better able to anticipate the future performance prospects of the organizations.

- Some of the firms also bear negative EVA, while they show positive net profits. The negative EVA implies that the cost of capital for such firms is quite higher. One reason for this might be the relative immaturity of the debt market in Pakistan, which is a relatively less costly source of the financing for the firms.

- Organizations should also take into account EVA in their planning and control process, whereby objectives relating to EVA should be set, monitored and evaluated. The objectives and relative strategies to achieve such goals should be realistic and objectively monitored.

- Regulators and other evaluation \& monitoring agencies like Pakistan Credit Rating Agency, Security \& Exchange Commission of Pakistan and Stock Market analysts also need to understand the value of contemporary 
performance measures and these should be reflected in their reporting and information requirements and other evaluation criteria.

\subsection{LIMITATIONS OF THE RESEARCH}

EVA although has provided an indication of a significant relationship with Pakistani industry,it had limited explanatory power with regard to the dependent variable of MAR. Further, certain risk factors and macroeconomic variables, which might have explanatory power for MAR, were not considered in the study. The study although meets its objectives, as the basic purpose of the study was to assess the relative importance of different performance measures on the value of the firm and this objective has properly been addressed in the study, the inclusion of other variables could enhance the explanatory power of the model.

\section{REFERENCES}

1. Abdeen, A. M. (2002). A fresh look at economic value added: Empirical study of the Fortune five-hundred companies. Journal of Applied Business Research, 18(2), 27-36.

2. Afza, T., \&Nazir, M. S. (2011).Working capital management efficiency of cement sector of Pakistan. Journal of Economics and Behavioral studies, 2(5), 223-235.

3. Alipour, M., \&Pejman, M. E. (2015). The impact of performance measures, leverage and efficiency on market value added: Evidence from Iran. Global Economics and Management Review, 20(1), 6-14.

4. AlOmoush, B. H., \& AL-Shubiri, F. N. (2013). The impact of multiple approaches financial performance indicators on stocks prices: An empirical study in Jordan. Journal of Global Business and Economics, 6(1), 1-11.

5. Arabsalehi, M. \&. Mahmoodi, (2012). The Quest for the Superior Financial Performance Measures. International Journal of Economics and Finance, 4(2), 116-126.

6. Bacidore, J. M., Boquist, J. A., Milbourn, T. T., \&Thakor, A. V. (1997).The search for the best financial performance measure. Financial Analysts Journal, 53(3), 11-20.

7. Baxendale, S. J., \& Bowen, L. (2015). Economic Value Added for New Ventures and Small Business. Journal of Small Business Strategy, 12(2), 41-51.

8. Bayrakdaroglu, A., Ersoy, E., \&Citak, L. (2012). Is There a Relationship Between Corporate Governance and Value-based Financial Performance Measures? A Study of Turkey as an Emerging Market.Asia-Pacific Journal of Financial Studies, 41(2), 224-239.

9. Biddle, G. C. (1997). Does EVA® beat earnings? Evidence on associations with stock returns and firm values. Journal of Accounting and Economics, 24(3), 301-336.

10. Bluszcz, A., \&Kijewska, A. (2016). Factors Creating Economic Value Added of Mining Company. Archives of Mining Sciences, 61(1), 109-123.

11. Bowen, R. J. (1989). Informational efficiency and the information content of earnings during the stock market crash of 1987. Journal of Accounting and Economics 11(2/3), 225-254.

12. Byrne, S. F. (1996). Eva ® and Market Value. Journal of Applied Corporate Finance, 9(1), 116-125.

13. Chetty, R., Friedman, J. N., \&Rockoff, J. (2016). Using Lagged Outcomes to Evaluate Bias in Value-Added Models. The American Economic Review, 106(5), 393-399. 
14. De Wet, J. H. (2005). EVA versus traditional accounting measures of performance as drivers of shareholder value-A comparative analysis. Meditari Accountancy Research, 13(2), 1-16.

15. De Wet, J. H. (2007). Return on equity: A popular, but flawed measure of corporate financial performance. South African Journal of Business Management, 38(1), 59-69.

16. Desai, M. F. (2006). Understanding economic value added. Harvard Business Review, 23(7), 1-23.

17. Dunbar, K. (2013). Economic Value Added (EVA TM): A Thematic-Bibliography. The Journal of New Business Ideas \& Trends, 11(1), 54

18. Farsio, F., Degel, J., \&Degner, J. (2000). Economic Value Added (EVA) and stock returns. The Financier, 115-119.

19. Fayed, A. M., \& Dubey, S. (2016). An Empirical Study of Impact of EVA Momentum on the Shareholders Value Creation as Compared to Traditional Financial Performance Measures-With Special Reference to the UAE. International Journal of Economics and Finance, 8(5), 23.

20. Fisher, F. M. (1983). On the misuse of accounting rates of return to infer monopoly profits. The American Economic Review, 73(1), 82-97.

21. Garvey, G. G. (2000). EVA versus Earnings: Does it matter which is more highly correlated with stock returns? Journal of Accounting Research, 38(3), 209-245.

22. Gujarati, D. N. (2009).Basic econometrics.Tata McGraw-Hill Education.

23. Hall, J. H. (2013). Toward improved use of value creation measures in financial decision-making.Journal of Applied Business Research (JABR), 29(4), 1175-1188.

24. Hall, J. H. (2016). Industry-specific determinants of shareholder value creation. Studies in Economics and Finance, 33(2).

25. Harcourt, G. C. (1965). The accountant in a golden age. Oxford Economic Papers, 17(1), 66-80.

26. Hassan, N. U. (2014). Do Pakistani Banks Create Value? Journal of Applied Environmental and Biological Sciences, 4(9S), 407-415.

27. Ismail, I. (2011). The ability of EVA (Economic Value Added) attributes in predicting company performance.African Journal of Business Management, 5(12), 4993-5000.

28. Ismail, M., Aslam, M. I., \&Zubair, M. (2014).Effect of traditional and modern performance instruments on selected companies from Pakistan. Science International (Lahore), 26(5), 2617-2619.

29. Jacobson, R. (1987). The validity of ROI as a measure of business performance. The American Economic Review, 77(3), 470478.

30. Kim, W. G. (2006). EVA and Traditional Accounting Measures: Which Metric is a Better Predictor of Market Value of Hospitality Companies? Journal of Hospitality \& Tourism Research, 30(1), 34-49.

31. Laing, G., \& Dunbar, K. (2015). EVA (TM) EPS, ROA and ROE as Measures of Performance in Australian Banks: A Longitudinal Study. Journal of Applied Management Accounting Research, 13(1), 41.

32. Lee, S. \& Kim W. G. (2009). EVA, refined EVA, MVA, or traditional performance measures for the hospitality industry? International Journal of Hospitality Management, 28(3), 439-445.

33. Machuga, S. M. (2002). Economic Value Added, Future Accounting Earnings, and Financial Analysts' Earnings Per Share Forecasts. Review of Quantitative Finance and Accounting, 18(1), 59-73. 
34. Marshall, A. (1890). Principles of Economics. The Macmillan Press Ltd., London, New York.

35. Moghaddam, A. G. (2012). A Study of Refined Economic Value Added Explanatory Power Associated with MVA \& EPS in Tehran Stock Exchange. Interdisciplinary Journal of Contemporary Research In Business, 3(9), 403-413.

36. Nakhaei, H. (2016). Market value added and traditional accounting criteria: Which measure is a best predictor of stock return in Malaysian companies.Iranian Journal of Management Studies, 9(2), 433.

37. Ott, R. L., \&Longnecker, M. (2001).Statistical methods and data analysis.Thomson Learning.

38. Owusu-Antwi, G., Mensah, L., Crabbe, M., \&Antwi, J. (2015). Determinants of Bank Performance in Ghana, the Economic Value Added (EVA) Approach. International Journal of Economics and Finance, 7(1), 203.

39. Panahian, H. \& Mohammadi H. (2011). Relative and Incremental Information Contents of Economic Value Added (EVA) and Refined Economic Value Added (REVA) used for Prediction of the Income. European Journal of Economics Finance and Administrative Sciences, 6(28), 96-103.

40. Panigrahi, S., Zainuddin, Y. B., \&Azizan, N. A. B. (2014).Investigating relationship between EVA and MVA of selected construction companies in Malaysia.The International Journal of Business \& Management, 2(6), 136.

41. Pourali, M. R., \&Roze, Z. (2013). The Relationship between Market Value Added with Refined Economic Value Added and Performance Accounting Criteria in the Firms listed in the Tehran Stock Exchange. International Research Journal of Applied and Basic Sciences, 4(6), 1636-1645.

42. Rajesh, M., Raman, R., \& Narayan, R. (2012).An empirical study on EVA and MVA approach. International Journal of Marketing, Financial Services \& Management Research, 1(3), 87-97.

43. Reece, J. S. (1978). Measuring investment center performance. Harvard Business Review, 56(3), 28-46.

44. Shah, R., Haldar, A., \&Nageswara Rao, S. V. D. (2015). Economic Value Added: Corporate performance measurement tool.

45. Sharma, A. K., \& Kumar, S. (2010). Economic value added (EVA)-literature review and relevant issues. International Journal of Economics and Finance, 2(2), 200.

46. Stewart, G. (1991). The Quest for Value. Harper Business, New York.

47. Wang, X. (2013). Research on evaluation of high-tech enterprises performance in zigong based on economic value added. International Journal of Digital Content Technology and its Applications, 7(2), 272.

48. Wirawan, D. I. (2011). Effects of EVA (Economic Value Added), EVA Spread, EVA Momentum and Return on Assets on Stock Return.

49. Wood, N. A. (2000). Economic value added (EVA): uses, benefits and limitations-a South African perspective. South African Business Review, 4(1), 1-12.

50. Yaqub, M. S. (2015). Is EVA a Better Performance Measure than Accounting Measures? Evidence from Pakistani Listed Companies. Science International (Lahore), 27(2), 1425-1432. 
